\title{
Neocortical Origin and Tangential Migration of Guidepost Neurons in the Lateral Olfactory Tract
}

\author{
Naomi Tomioka, ${ }^{1}$ Noriko Osumi, ${ }^{2}$ Yasufumi Sato, ${ }^{1,3}$ Takayoshi Inoue, ${ }^{4}$ Shun Nakamura, ${ }^{4}$ Hajime Fujisawa, ${ }^{1,5}$ \\ and Tatsumi Hirata ${ }^{3,5,6}$ \\ ${ }^{1}$ Division of Biological Science, Nagoya University Graduate School of Science, Chikusa-ku, Nagoya 464-8602, Japan, \\ 2Department of Developmental Neurobiology, Tohoku University Graduate School of Medicine, Aoba-ku, Sendai 980-8575, \\ Japan, ${ }^{3}$ Division of Brain Function, National Institute of Genetics, Mishima 411-8540, Japan, ${ }^{4}$ Division of Biochemistry and \\ Cellular Biology, National Institute of Neuroscience, Kodaira 187-8501, Japan, ${ }^{5}$ Core Research for Evolution Science and \\ Technology, and 6Precursory Research for Embryonic Science and Technology, Japan Science and Technology \\ Corporation (JST), Kawaguchi 332-0012, Japan
}

The early-generated neurons designated as lot cells specifically mark the future site of the lateral olfactory tract (LOT) and guide LOT axons. We investigated the mechanism of how lot cells develop and get localized in the LOT position. Lot cells differentiated from neuroepithelial cells in all regions of the neocortex but not from those in the ganglionic eminence in culture. Cell tracing analyses demonstrated that lot cells generated from the neocortex subsequently followed a tangential migration stream ventrally toward the LOT position. Mutant mouse embryos lacking the function of transcription factor Gli3 showed disturbances of the migration stream and translocation of lot cells in the dorsal telencephalon. These results reveal a new type of neuronal migration in the telencephalon and introduce an unexpected dramatic feature of the earliest regionalization of the telencephalon.

Key words: migration; neurogenesis; guidepost; lot cell; Gli3; Xt
In the developing telencephalon, a large number of neurons originate from neuroepithelial cells lining the ventricular zone. Most of them migrate outward to the surface along radial glial fibers (Tan and Breen, 1993; Kornack and Rakic, 1995), whereas a minority of them follow a tangential migration course from ventral to dorsal for a relatively long distance (O'Rourke et al., 1992; Anderson et al., 1997; Tamamaki et al., 1997). Regardless of the migration course, however, all neurons must acquire a specific identity suitable for settlement at some time during development.

One way to impose regional identity on neurons is to specify their progenitors in the ventricular zone and simply transfer the specification to neurons at the surface. A strict radial migration of newly generated neurons would guarantee this process and help the reconstruction of a map across the horizontal plane of the brain from the original presentation in the ventricular zone (Rakic, 1988). In fact, the two major divisions in the telencephalon, the neocortex and ganglionic eminence, appear to use this mechanism for their specification; neuroepithelial cells in the two regions express different sets of genes from the early beginning and do not mix with each other during development (Bulfone et al., 1993; Fishell et al., 1993; Matsunami and Takeichi, 1995; Götz et al., 1996; Stoykova et al., 1996). Although it is unlikely that this sort of compartmentalization functions for smaller subdivisions in the telencephalon such as cortical areas, early regionalization of the telencephalon has been supported by a number of studies using

\footnotetext{
Received Feb. 24, 2000; revised May 9, 2000; accepted May 12, 2000.

This work was supported by grants from the Ministry of Education and Science and Culture (Japan) and Precursory Research for Embryonic Science and Technology (PRESTO) and Core Research for Evolution Science and Technology (CREST) of Japan Science and Technology Corporation (JST). We thank Dr. Masaharu Ogawa of RIKEN, Dr. Keiko Hayashi-Takiguch of Mitsubishi Kasei Institute of Life Sciences, Dr. Nobuaki Tamamaki of Kyoto University, and Dr. Hiroshi Sasaki of Osaka University for helpful advice, Dr. Magdalena Götz of Max-Planck Institute and Dr. Fujio Murakami of Osaka University for critical reading of this manuscript, and Yoshiko Takagi for technical assistance. We also thank Dr. Masaru Okabe, Dr. Toshihiko Shiroishi, and Dr. Randall R. Reed for the generous gifts of green mice, $X t^{\mathrm{J}}$ mutant mice, and anti-pax6 antibody, respectively.

Correspondence should be addressed to Dr. Tatsumi Hirata, Division of Brain Function, National Institute of Genetics, Yata 1111, Mishima 411-8540, Japan. E-mail: tathirat@lab.nig.ac.jp.

Copyright (C) 2000 Society for Neuroscience $0270-6474 / 00 / 205802-11 \$ 15.00 / 0$
}

various region-specific markers (Barbe and Levitt, 1991; Arimatsu et al., 1992; Dehay et al., 1993; Cohen-Tannoudji et al., 1994). There is also a contrasting view that regional identity is instructed in neurons only after their maturation (O'Leary et al., 1992). Heterotopic transplantation studies have shown that neuronal wiring patterns and cytoarchitectural phenotypes in the telencephalon are changeable even in late fetal stages (Stanfield and O'Leary, 1985; Schlaggar and O'Leary, 1991). In this view, neuroepithelial cells and newly generated neurons are not specified yet and acquire regional identity by environmental influence. Tangential migration of neurons across a number of telencephalic regions is often interpreted to support this view of later regional specification (Walsh and Cepko, 1992) because the migration would scramble positional information, if any, existing in the ventricular zone.

The stereotyped axonal trajectory is another type of regional specification that has attracted a number of researchers (TessierLavigne and Goodman, 1996). Soon after completing mitosis, neurons project axons into a specific position in the brain, where axons traversing through the same route are bundled together forming "tracts" (Mastick and Easter, 1996). Because the early tract formation coincides with neurogenesis, neuroepithelial cells and early-generated neurons seem to play a critical role in providing positional information for axons (Macdonald et al., 1994; Mastick et al., 1997).

The lateral olfactory tract (LOT) projects a prominent arch on the surface of piriform cortex from embryonic day 13.0 (E13.0) in mice (see Fig. 1) (Schwob and Price, 1984; Brunjes and Frazier, 1986; Sugisaki et al., 1996). Mitral cells in the olfactory bulb are the major projection source of this tract (Hinds, 1972). We reported previously that a subset of early-generated neurons, which are recognized by monoclonal antibody (mAb) lot1 and designated as lot cells, specifically marks the future site of the LOT and provides the cellular scaffold for the first mitral cell axons to elongate (see Fig. 1A) (Sato et al., 1998). Because ablation of lot cells prohibits the formation of LOT in organotypic culture, we postulated that the lot cells act as the guidepost for mitral cell axons (Sato et al., 1998). Lot cells undergo final mitosis between E9.5 and E11.0 and begin to express the antigen of mAb lot1 (lot-antigen) at approximately E12.0-12.5. When lot cells are first visualized by immuno- 
staining at these stages, the cells are already localized around the presumptive LOT position, where the cells positioned on the ventral side start to form a packed cellular array (Sato et al., 1998). The relatively scattered distribution of lot cells on the dorsal side suggested a possibility that lot cells originate from the dorsal side and locate in the LOT position.

In the present study, we investigated how the LOT position was specified during development by analyzing the development of lot cells in various cultures. We found that lot cells differentiated in dissociated cultures of neuroepithelial cells from all regions of the neocortex but not of the ganglionic eminence. Neocortical neuroepithelial cells appeared to intrinsically possess the competence to generate lot cells. Cell-tracing experiments in whole embryo culture suggested that lot cell precursors that had differentiated in the entire neocortex migrated tangentially and ventrally to the future site of the LOT with an unreported migration stream. We also found that this migration stream was disturbed in extra-toes $(X t)$ mouse embryos, which have mutations in the transcription factor Gli3 gene (Johnson, 1967; Schimmang et al., 1992; Hui and Joyner, 1993), and lot cells were abnormally distributed all over the neocortex. These results suggest the two-stepped nature of the specification of LOT position: first to restrict the competence for lot cell generation to the large neocortex region and then to translocate the cells destined for lot cell fate into a small restricted area by tangential migration.

\section{MATERIALS AND METHODS}

Mice. Timed-pregnant ICR mice and C57BL $+/+$ mice were purchased from SLC (Shizuoka, Japan). C57BL/6-green mice whose cells express enhanced green fluorescent protein (GFP) were provided by Dr. Masaru Okabe (Osaka University) (Okabe et al., 1997). Green male mice were mated with wild-type female, and the resulting green mouse embryos were selected under UV light. $X t^{\mathrm{J}} /+$ mice were originally obtained in the $\mathrm{C} 3 \mathrm{HeB} / \mathrm{Fej}$ background from Dr. Toshihiko Shiroishi (National Institute of Genetics) and maintained in our laboratory by crosses with C57BL/6$+/+$ mice. $X t^{\mathrm{J}} /+$ heterozygous mice were determined by the extra digits in the hind feet. $X t^{\mathrm{J}} / X t^{\mathrm{J}}$ homozygous embryos were obtained by intercrosses between heterozygotes on the fifth or sixth generation in backcrosses with C57BL/6 mice and distinguished from $X t^{\mathrm{J}} /+$ and $+1+$ litter embryos by the overgrowth of the first pharyngeal arch and malformations in the brain as described previously (Johnson, 1967; Franz, 1994; Grove et al., 1998). Although $X t^{\mathrm{J}} / X t^{\mathrm{J}}$ mutant embryos in $\mathrm{C} 3 \mathrm{HeB} / \mathrm{Fej}$ background often show exencephaly with severe disruption of the telencephalon, crosses with mice in the $\mathrm{C} 57 \mathrm{BL} / 6$ background completely prohibited the appearance of this phenotype and enhanced morphological analysis. The phenotype described in the present study, however, was not affected by these backgrounds. Because $X t^{\mathrm{J}} /+$ mouse embryos do not show any brain phenotypes (Johnson, 1967; Franz, 1994; Grove et al., 1998), we dealt with these heterozygotes as the wild-type in the present study.

Midday on which a vaginal plug was found was designated as E0.5. Development of embryos in $\mathrm{C} 57 \mathrm{BL} / 6$ and $\mathrm{C} 3 \mathrm{HeB} / \mathrm{Fej}$ backgrounds was slightly retarded when compared with ICR embryos of the same stage. For example, initiation of expression of lot-antigen was delayed $\sim 0.5 \mathrm{~d}$; however, this retardation did not affect the experimental results.

Dissociated cell culture. Telencephalon vesicles were dissected out from E10.5 or E11.5 embryos, and the rostral and caudal ends were trimmed away and cut into four sections as described in Results. Telencephalon sections of several embryos were pooled and collectively incubated in $0.1 \%$ trypsin/HCMF (10 mM HEPES, $137 \mathrm{~mm} \mathrm{NaCl}, 5.4 \mathrm{~mm} \mathrm{KCl}, 1 \mathrm{~mm} \mathrm{KH} \mathrm{H}_{2} \mathrm{P}_{4}$, and $1 \mathrm{~mm} \mathrm{Na} \mathrm{HPO}_{4}$ ) for $5 \mathrm{~min}$ at $37^{\circ} \mathrm{C}$ and dissociated into single cells by gentle pipetting. Cells were plated at a density of $1.0 \times 10^{3}$ cells $/ \mathrm{mm}^{2}$ on eight chamber permanox slides (Nalge Nunc, Naperville, IL) coated with poly-L-lysine (Sigma, St. Louis, MO), and cultured in a 1:1 mixture of DMEM and Ham's F-12 medium (DMEM/F-12) (Nissui, Tokyo, Japan) supplemented with $10 \%$ fetal bovine serum (JRH Biosciences, Lenexa, KS) and 5\% horse serum (Life Technologies, Rockville, MD) in an atmosphere containing $5 \%$ carbon dioxide at $37^{\circ} \mathrm{C}$ for $5 \mathrm{~d}$. To detect cells in S-phase in culture, $100 \mathrm{ng} / \mathrm{ml}$ of 5-bromo-2-deoxyuridine (BrdU; Sigma) was added in the culture media in some experiments.

The low density culture of telencephalon cells of $X t^{\mathrm{J}} / X t^{\mathrm{J}}$ mutant and the litter embryos was performed with a slight modification of the previous methods (Miyata and Ogawa, 1994; Sakakibara et al., 1996). Briefly, a circle of silicone ring with an inner area of $50 \mathrm{~mm}^{2}$ was placed on the bottom of a poly-L-lysine-coated chamber slide, and glial cells that had been prepared from brains of E17.5-18.5 mouse embryos through several passages were seeded outside the ring as a feeder. Dissociated telencephalon cells were plated inside the ring at a density of $2 \times 10^{2}$ cells $/ \mathrm{mm}^{2}$. After attachment of telencephalon cells on the slide, the silicone ring was gently removed, and cells were cultured in DMEM/F-12 supplemented with $10 \%$ fetal bovine serum, 5\% horse serum, N-2 supplement (Life Technologies), G-5 supplement (Life Technologies), and $50 \mathrm{ng} / \mathrm{ml}$ neuro- trophin 3 (NT-3) (Pepro Tech, Rocky Hill, NJ) at $37^{\circ} \mathrm{C}$ for $5 \mathrm{~d}$ under a continuous supply of nutrition released from glial cells. After culture, cells were fixed and immunostained with various antibodies. Immunopositive cells were counted under a fluorescent microscope (Zeiss, Jena, Germany) using a square micrometer attached to an eyepiece. Cells stained with diaminophenylindole were also counted in the same manner.

Clonal cell cultures. Glial cells that had been prepared as described above were cultured in an eight-chamber slide until they formed a confluent monolayer. A single cell was picked up from dissociated cells that had been prepared from E10.5 green mouse telencephalons by a fine glass capillary under an inverted microscope (Olympus, Tokyo, Japan). The cell was placed on the glial feeder layer and cultured in DMEM/F-12 supplemented with 10 mM HEPES, pH 7.3, 5\% horse serum, N-2 supplement, G-5 supplement, and $50 \mathrm{ng} / \mathrm{ml} \mathrm{NT}-3$ at $37^{\circ} \mathrm{C}$ for $5 \mathrm{~d}$.

Culture of telencephalon fragments. E10.5 telencephalons were cut into small fragments as described in the text. Fragments derived from the same region were cultured together in a well of poly-L-lysine-coated eightchamber slide with DMEM/F-12 containing $10 \%$ fetal bovine serum and $5 \%$ horse serum at $37^{\circ} \mathrm{C}$ for $5 \mathrm{~d}$. Because lot cells formed clusters during culture, it was easy to spot those fragments containing lot cells after immunostaining with $\mathrm{mAb}$ lot1. Fragments with and without lot cells were counted, and the proportion of fragments that generated lot cells was calculated.

Immunostaining. Cultures were fixed with $4 \%$ paraformaldehyde (PFA) in PBS for $4 \mathrm{hr}$ and incubated overnight with $\mathrm{mAb} \operatorname{lot} 1(10 \mu \mathrm{g} / \mathrm{ml})$ and with anti-MAP2 antibody (1:500; Sigma) in $1 \%$ skim milk/TBST (10 mm Tris- $\mathrm{HCl}, \mathrm{pH} 7.4,130 \mathrm{~mm} \mathrm{NaCl}$, and $0.1 \%$ Tween 20$)$. Bound antibodies were visualized with Cy3-labeled anti-rat Ig antibody (1:500; Amersham, Buckinghamshire, UK) and FITC- or Cy5-labeled anti-mouse Ig antibody (1:200; Amersham). BrdU-incorporated cells were detected with mouse anti-BrdU antibody (1:100; Becton Dickinson, Franklin Lakes, NJ) and FITC-labeled anti-mouse Ig antibody as described previously (Sato et al., 1998).

The methods used for immunostaining of frozen sections with mAb lot1 were similar to those described previously (Sato et al., 1998). Rabbit anti-Pax6 antibody was a generous gift from Dr. Randall R. Reed (Johns Hopkins University School of Medicine) (Davis and Reed, 1996), and FITC-labeled anti-rabbit Ig antibody (1:200; Amersham) was used for visualization.

Whole-mount immunostaining basically followed the previous procedures (Sugisaki et al., 1996; Sato et al., 1998; Hirata and Fujisawa, 1999). When 3,3'-diaminobenzidine was used for visualization, specimens were treated with TSA-indirect kit (NEN Life Science, Boston, MA) and streptavidin-HRP (NEN Life Science) to amplify the immunoreaction.

Detection of migration of neocortical cells. The methods used for cell labeling and whole-embryo culture have been described previously (Matsuo et al., 1993; Osumi-Yamashita et al., 1994). Briefly, E10.5 mouse embryos were removed from the uterus into Tyrode's solution with intact placenta and embryonic membranes. A small drop of 1,1-dioctadecyl3,3,3'3'-tetra-methylindocarbacyanine perchlorate (DiI, Molecular Probes, Eugene, OR) solution was injected into the ventricular zone of the neocortex hemisphere with a fine glass capillary tube under a dissecting microscope. The embryos were cultured in culture bottles containing $100 \%$ rat serum supplemented with $2 \mathrm{mg} / \mathrm{ml}$ of glucose in a roter apparatus with a continuous supply of a gas mixture $(60-90 \%$ oxygen $/ 5 \%$ carbon dioxide balanced with nitrogen) at $37^{\circ} \mathrm{C}$ for $48 \mathrm{hr}$. After fixation of embryos with $4 \%$ PFA, telencephalons were dissected out and examined under a fluorescent microscope. Brains of some embryos were embedded in $2 \%$ agarose in PBS and cut into 60- $\mu \mathrm{m}$-thick sections with a microslicer (Dosaka EM, Kyoto, Japan)

In some experiments, the solution containing the expression plasmid pCAX-AFP $(5 \mu \mathrm{g} / \mu \mathrm{l})$ that coded for a mutant form of GFP (Inouye et al., 1997) was injected into the ventricle of E10.5 embryos and electroporated into ventricular cells in the neocortex with a T 820 electroporator (BTX, San Diego, CA) as described (Akamatsu et al., 1999; T. Inoue, T. Tanaka, M. Takeichi, O. Chisaka, S. Nakamura, N. Osumi, unpublished observations). The embryos were cultured as a whole for $48 \mathrm{hr}$, and then the piriform cortex explants were immediately dissected from the embryos and organotypically cultured on collagen-coated membrane filters (TranswellCOL, Costar, Cambridge, MA) as described previously (Sugisaki et al., 1996; Hirata and Fujisawa, 1999).

\section{RESULTS}

\section{Development of lot cells in dissociated culture of neocortical neuroepithelial cells}

The previous observation that $\mathrm{mAb}$ lot1 only recognizes neurons localized around the LOT position (Sato et al., 1998) might suggest that an environmental signal from the LOT position is essential for neurons to express the lot-antigen. Thus, we first tested whether lot cells could differentiate in dissociated cultures of embryonic telencephalon cells, which were considered to be devoid of environmental signal from LOT position. At E10.5, neurogenesis has just commenced, and the telencephalon mostly consists of neuroepithelial cells. At this stage, the two major divisions of the telencepha- 
A

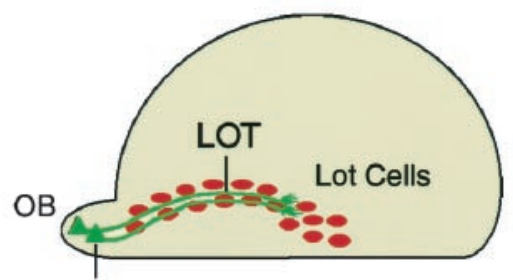

Mitral Cells

B
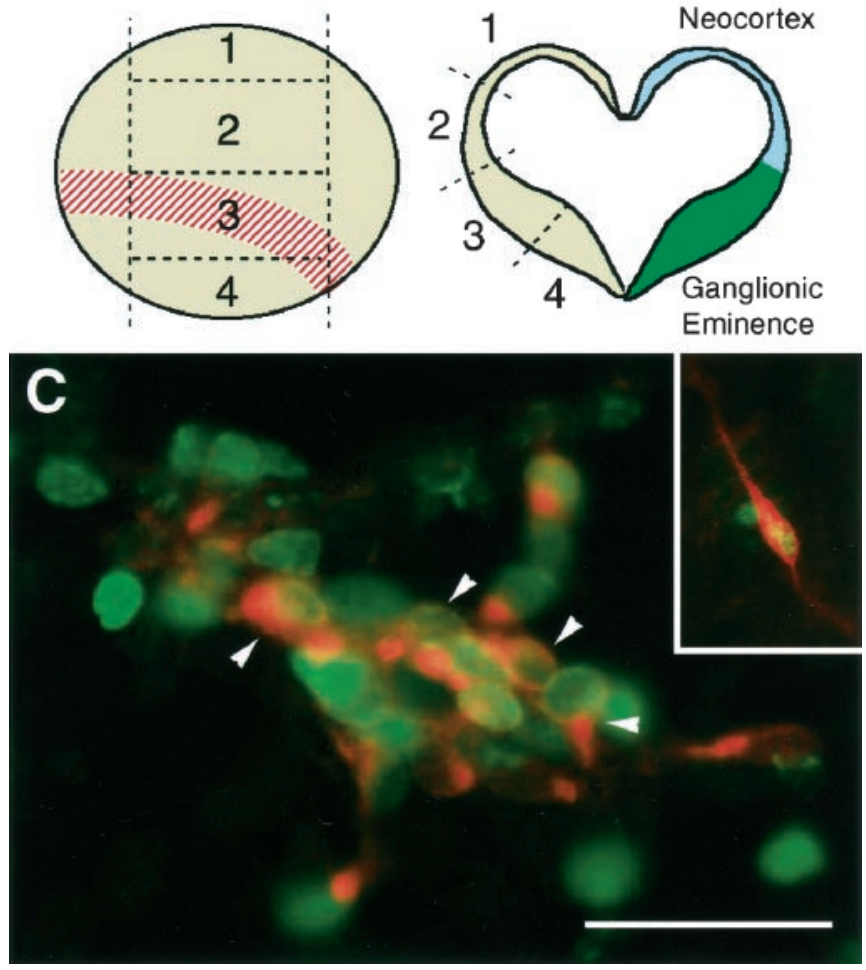

Figure 1. Lot cells in the telencephalon and in dissociated culture of telencephalon cells. $A$, A schematic drawing of the lateral view of the E13.5 mouse telencephalon. The dorsal aspect is to the top and rostral is to the left. Lot cells, the earliest-generated neurons in the telencephalon, form an arched cellular array on the surface of developing piriform cortex. Mitral cells, the main output neurons of the olfactory bulb $(O B)$, project axons on the lot cell array and form the lateral olfactory tract $(L O T)$. B, Lateral (left $)$ and coronal (right) views of the E10.5 telencephalon. The dorsal aspect is to the top in both views, and rostral is to the left in the lateral view. Telencephalon was dorsoventrally dissected into four regions. Regions 1 and 2 are from the neocortex, and regions 3 and 4 are from the ganglionic eminence. The position where the LOT is supposed to develop is shown by the area filled with red oblique lines (left). C, The E10.5 telencephalic cells from region 1 were dissociated and cultured for $5 \mathrm{~d}$ in the presence of BrdU. The culture was doubly stained with mAb lot1 (red) and anti-BrdU antibody (green). Approximately half of the lot cells that differentiated in culture incorporated BrdU in their nuclei (arrowheads). The inset shows the typical bipolar morphology of the lot cell in the more scattered part of dissociated culture. Scale bar, $50 \mu \mathrm{m}$.

lon, the neocortex in the dorsal part and the ganglionic eminence in the ventral prominent part, are already distinct (Fig. 1B). Because lot cells are the earliest-generated neurons in the telencephalon, most of these cells are going through the final mitoses at this stage, although mitosis has already been completed in a fraction of these cells (Sato et al., 1998). We divided the E10.5 telencephalon into the neocortex and ganglionic eminence and further divided each part dorsoventrally into two halves; regions 1 and 2 extended from the neocortex, whereas regions 3 and 4 extended from the ganglionic eminence (Fig. $1 B$ ). Each region was dissociated into single cells and cultured for $5 \mathrm{~d}$ in the continuous presence of BrdU to trace cell proliferation.
Telencephalic cells from all four regions proliferated well, and cell numbers increased in dissociated cultures, although the culture form region 1 tended to generate fewer cells compared with the other three regions (Table 1). These cultures also generated similar numbers of neurons when determined by the expression of a neuronal marker, microtubule-associated protein 2 (MAP2). Lot cells differentiated in cultures of regions 1 and 2 (Table 1). These lot cells displayed bipolar shapes equipped with two processes and morphologically resembled lot cells in vivo (Fig. $1 C$ ). The numbers of lot cells that developed from regions 1 and 2 were not significantly different, and approximately half of these cells incorporated BrdU in their nuclei (Table 1), indicating that they had divided in culture at least once. In contrast, cultures of regions 3 and 4, which originated from the ganglionic eminence, generated very few lot cells (Table 1). These results suggest that an environmental signal from the LOT position is not needed for the development of lot cells and that neocortical cultures but not ganglionic eminence cultures can generate lot cells.

Lot cells undergo their final mitoses during a narrow window of time in vivo. After E11.5, injection of BrdU does not label a significant number of lot cells (Sato et al., 1998). To examine whether this time window was also defined in the culture, we assayed E11.5 telencephalon cells in dissociated cultures. When telencephalons of E11.5 embryos were divided into the four regions and cultured, cells from all four regions generated MAP2-positive neurons as did E10.5 telencephalon cells (Table 2). Lot cells differentiated in these cultures as well but rarely incorporated BrdU in their nuclei (Table 2), indicating that the majority of these cells had already completed the final S-phase when isolated from the telencephalon. These findings suggest that the culture of E11.5 neuroepithelial cells almost loses the ability to give rise to lot cells and that this temporal change is related to the cessation of lot cell generation after E11.5.

Another interesting point of E11.5 telencephalon cell cultures is that more lot cells differentiated from the ventral regions and fewer cells differentiated from region 1, compared with E10.5 cell cultures (Table 2). This ventral shift appeared to reflect a change in the distribution of postmitotic neurons destined for lot cell fate because the cells hardly incorporated BrdU regardless of their position. The presumptive LOT position is estimated to develop at around region 3 (Fig. $1 B$ ). Thus, this result might imply that lot cell precursors approached their final position after completing their mitoses.

\section{Competence to generate lot cells is an intrinsic property of neocortical neuroepithelial cells}

In dissociated cell cultures, a small but substantial number of telencephalon cells were cultured together in a well. Thus, it is possible that extrinsic influences by other cells affect determination of lot cell fate in culture. For example, neocortex cultures might contain some environmental factors that promote lot cell generation, or ganglionic eminence cultures might contain factors that inhibit differentiation into lot cells. Alternatively, it is possible that neuroepithelial cells in the neocortex are cell-autonomously different from those in the ganglionic eminence with regard to competence for lot cell generation. To know the actual scenario, we cultured a single neuroepithelial cell and analyzed cell fates of its descendants.

Neuroepithelial cells as early as E10.5 did not proliferate or survive in a totally isolated condition. Thus, we used the feeder layer of glial cells. A single cell was picked up from E10.5 telencephalic cells that had been prepared from green mouse embryos whose cells strongly express enhanced GFP (Okabe et al., 1997) and placed on the feeder layer. While being cultured for $5 \mathrm{~d}$, a single neuroepithelial cell proliferated and formed a colony that was easily identifiable by the GFP expression. In neocortical cell cultures, we identified 43 independent colonies that consisted of cells ranging from 2 to 37 in number (Fig. 2A). Among these colonies, approximately one-third contained lot cells. We did not find any correlation between the colony size and generation of lot 
Table 1. Cell composition in dissociated cultures of E10.5 telencephalon cells

\begin{tabular}{llllll} 
Region & Total cells & BrdU-incorporated cells & MAP2-positive cells & Lot cells & BrdU-incorporated lot cells \\
\hline 1 & $150.3 \pm 7.5$ & $87.2 \pm 8.9$ & $42.8 \pm 2.9$ & $13.8 \pm 1.1^{a}$ & $8.0 \pm 0.9^{a}$ \\
2 & $153.6 \pm 6.3$ & $95.0 \pm 5.6$ & $57.2 \pm 4.9$ & $16.7 \pm 1.6^{a}$ & $8.9 \pm 1.1^{a}$ \\
3 & $154.5 \pm 7.8$ & $97.7 \pm 5.6$ & $53.8 \pm 5.0$ & $1.7 \pm 0.4$ & $1.0 \pm 0.7$ \\
4 & $151.3 \pm 8.6$ & $93.8 \pm 5.5$ & $48.4 \pm 3.5$ & $2.4 \pm 1.3$ & $0.9 \pm 0.4$
\end{tabular}

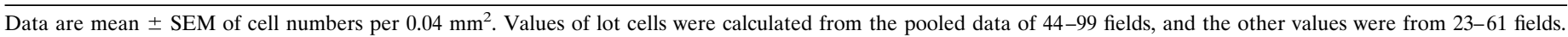
${ }^{a} p<0.001$ compared with cultures of region 4 (Student's $t$ test).

Table 2. Cell composition in dissociated cultures of E11.5 telencephalon cells

\begin{tabular}{llllll} 
Region & Total cells & BrdU-incorporated cells & MAP2-positive cells & Lot cells & BrdU-incorporated lot cells \\
\hline 1 & $163.7 \pm 16.6$ & $81.4 \pm 10.3$ & $40.7 \pm 3.5$ & $1.1 \pm 0.2$ & $0.2 \pm 0.1$ \\
2 & $152.8 \pm 12.5$ & $92.8 \pm 6.3$ & $47.7 \pm 4.1$ & $9.9 \pm 1.0^{a}$ & $1.1 \pm 0.2$ \\
3 & $164.1 \pm 17.8$ & $89.5 \pm 9.7$ & $47.8 \pm 7.0$ & $6.4 \pm 0.9^{a}$ & $0.2 \pm 0.1$ \\
4 & $165.3 \pm 12.8$ & $92.7 \pm 10.5$ & $52.0 \pm 3.8$ & $3.1 \pm 0.7$ & - \\
\hline
\end{tabular}

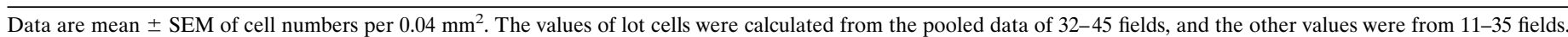
${ }^{a} p<0.001$ compared with cultures of region 4 (Student's $t$ test).

cells. Ganglionic eminence cells generated similar-sized colonies, but none contained lot cells (Fig. 2B). Thus, differences in intrinsic properties of neuroepithelial cells between the neocortex and ganglionic eminence appear to be the basis for the distinct generation of lot cells.

Interestingly, most neocortical clones containing lot cells also included lot-negative neurons (Fig. $2 A$ ), indicating that lot cell progenitors followed a lineage that generated both lot-positive and lot-negative neurons. Thus, lot cell fate did not seem to be clonally determined. This notion might be consistent with the observation that lot cells are generated for only a limited time, although a neuroepithelial cell continually generates clonally related sibling cells for a protracted time period during development.

\section{Widespread origin of lot cells across the neocortex}

In dissociated cultures of E10.5 telencephalon cells, both regions 1 and 2 in the neocortex generated lot cells. To determine which specific region of the neocortex could generate lot cells, we dissected the E10.5 neocortex into smaller fragments and analyzed the generation of lot cells in each fragment (Fig. $3 A$ ). Because such small fragments did not yield a sufficient number of cells for dissociated culture, they were cultured as a whole without dispersion into single cells in this experiment.

All neocortical fragments generated lot cells in a high probability (Fig. $3 A$ ), and the number of lot cells developed in the fragments seemed similar among the neocortical regions. In fragment cultures, lot cells were often observed to clump together and form a cluster (Fig. 3B), although we could not find a general rule with regard to the position of clusters in fragments. Only a few fragments from the ganglionic eminence generated lot cells (Fig. 3A). Because it was difficult to define the caudal end of the ganglionic eminence, a dorsoventral division in the caudal end of the telencephalon did not seem to correspond to the border between neocortex and ganglionic eminence. Here, both ventral and dorsal divisions generated lot cells in high proportions (Fig. $3 A$ ). Finally, although the fragment cultures allowed neuroepithelial cells to be in contact with their neighbor cells and remain in the original environment to some extent, this environmental influence appeared to have little effect on lot cell development; lot cells were generated from the neocortex but not from the ganglionic eminence, as was the case for dissociated cell and clonal cultures.

\section{Ventral migration of neurons in the E10.5 telencephalon}

Given that lot cells develop throughout the neocortex in vivo, they have to migrate down to the presumptive LOT position for a distance. However, such a ventral migration stream of neurons has not been described. To examine whether this type of cell migration

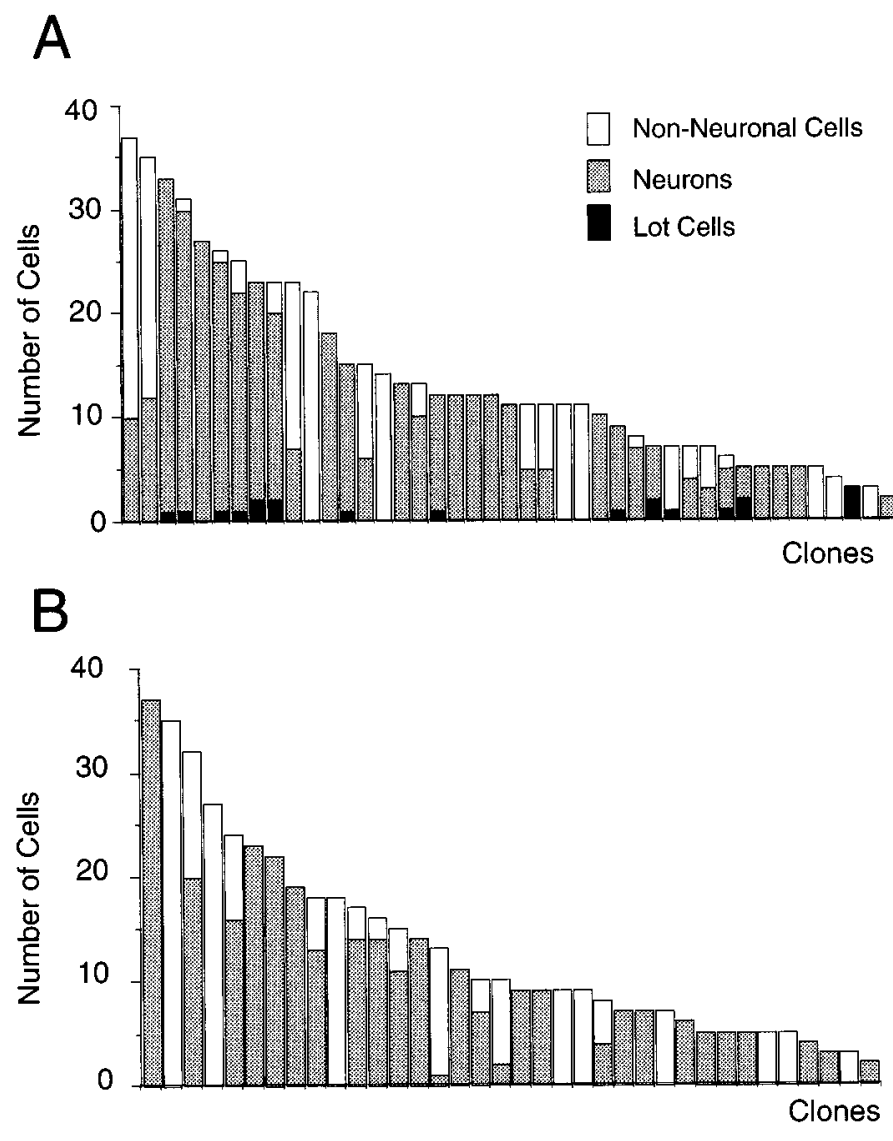

Figure 2. Composition of cell types in neuroepithelial clones. E10.5 telencephalon cells from the neocortex $(A)$ and ganglionic eminence $(B)$ were clonally cultured, and cell types in the developed clones were analyzed. Each column contains the data of one clone, and columns are arranged in the order of colony sizes. The numbers of lot cells, lot-negative MAP2positive neurons, and MAP2-negative non-neuronal cells are shown in black, gray, and white, respectively.

actually existed in the telencephalon, we labeled a small population of neuroepithelial cells in the neocortex of E10.5 embryo by focal injection of the fluorescent dye DiI, cultured the labeled embryo as a whole for $48 \mathrm{hr}$ in a roller bottle, and analyzed the behavior of the descendants of the DiI-labeled cells.

DiI intensely labeled cells around the injection point, obscuring 
Figure 3. Generation of lot cells in cultures of small fragments from various telencephalic regions. $A$, A lateral view of E10.5 telencephalon as in Figure $1 B$. The telencephalon was divided into 14 sections. The area filled with oblique lines indicates where the LOT is estimated to develop. The number in each section indicates the proportion of fragments that generated lot cells over the number of total fragments that were cultured. A couple of numbers indicated on the top outside the telencephalon (82 and 90) are the proportions of fragments from the dorsomedial side of the telencephalon. Each number was calculated from pooled data of 12-25 fragments in four independent cultures. $B$, Lot cells forming a cluster on the surface of a neocortex fragment (arrowheads). Scale bar, $100 \mu \mathrm{m}$.
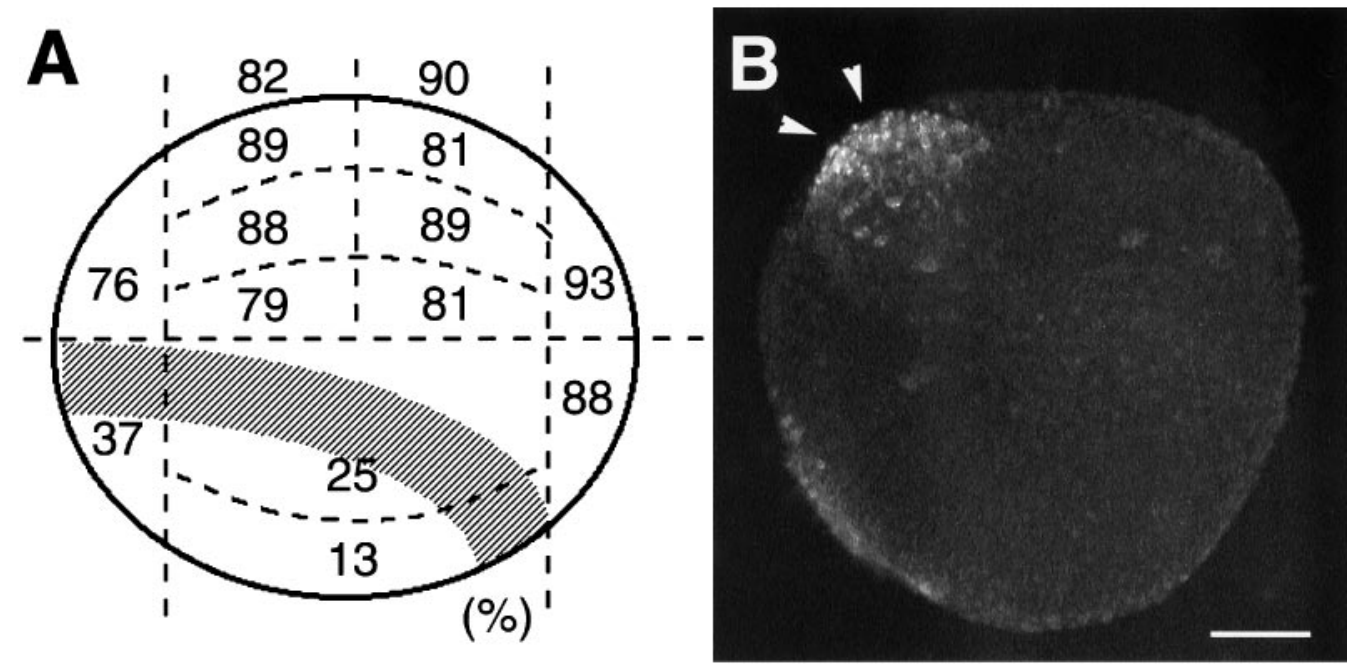

local migration of cells around the point such as a radial migration (Fig. 4A,B). However, examination of DiI-labeled cells that were clearly separated from the injection point showed that almost all of these cells migrated tangentially and ventrally from the injection point toward the presumptive LOT position (Fig. $4 A$ ). These cells were bipolar-shaped and displayed features characteristic of migrating neurons. Thick leading processes of these cells all oriented in a ventral direction (Fig. $4 C$ ). The cells seemed to migrate in the thin surface layer of the telencephalon to the presumptive LOT position (Fig. 4B). Around the LOT position, DiI-labeled cells orthogonally changed the orientation, drawing an inverted " $\mathrm{T}$ " shape in the surface of the telencephalon (Fig. 4A). Many DiIlabeled cells were piled up in layers and accumulated in the LOT position, which was exclusive to lot cells in vivo (Fig. $4 B$ ). The long processes of DiI-labeled cells were aligned in the future direction of LOT, arching across the surface of the piriform cortex (Fig. 4D). These morphological features were indeed of lot cells except that a fraction of DiI-labeled cells were also distributed in a slightly deeper layer of the piriform cortex in which lot cells are not usually situated (Fig. 4B). The DiI injections at any point across the neocortex showed a similar migration stream. For example, injections in the caudal part of the neocortex labeled neurons migrating in the rostroventral direction and aligning in the LOT position that arched in the caudal level of the telencephalon. Injections in the dorsomedial side of the neocortex, even near the hippocampal primordium, visualized neurons climbing over the dorsal bulge of the telencephalon and approaching the LOT position over a great distance (data not shown).

This migration stream of neurons appeared to be prominent only for a short time period. When neuroepithelial cells of the E11.5 neocortex were labeled with the DiI and distribution of the descendants was analyzed in the same way, migration of DiI-labeled cells was less directional (Fig. 4E). Although many cells still migrated ventrally, the migration speed apparently slowed down, and DiIlabeled cells were scattered over the neocortex. These cells displayed more complex morphology than the simple bipolar shape in the telencephalon given the DiI injection at E10.5. Some of the DiI-labeled cells elongated multiple processes and appeared to settle down in the position (Fig. $4 F$ ).

\section{Expression of lot-antigen in neurons that ventrally migrated from the neocortex}

We next examined whether neurons that had migrated from the neocortex to the LOT position actually differentiated into lot cells with expressing lot-antigen. To this end, we had to circumvent two major problems. First, because immunostaining with lot1 requires the continuous presence of detergent, lipophilic dyes such as DiI are diffused in the process of immunostaining and obscure the labeling. Thus, we injected the expression plasmid for GFP into the ventricle of E10.5 mouse embryos and electroporated the plasmid selectively into the ventricular zone of the dorsal neocortex with a pair of electrodes placed in an appropriate direction. When these embryos were cultured as a whole for $2 \mathrm{~d}$, the ventral migration of cells brightly expressing GFP was clearly visualized (Fig. $5 A$ ) as by the labeling with DiI. Furthermore, after fixation, the GFP labeling was not affected by the detergent treatment.

The second problem was more serious. Even when E10.5 embryos were cultured for up to a maximum of $48 \mathrm{hr}$, so that the embryos grew up to E12.5 theoretically, the lot-antigen got expressed only weakly in the embryos. With such a weak fragmental expression of lot-antigen, it was impossible to determine which cell body actually expressed the lot-antigen. We considered that the slight retardation of development in whole embryo culture delayed the expression of lot-antigen, which usually starts from E12.0-12.5, and performed additional cultures of the piriform cortex explants prepared from the embryos. When the piriform cortex explants including the LOT position were prepared from the GFP-labeled embryos that had been cultured for $2 \mathrm{~d}$ as a whole and cultured organotypically on a membrane filter for an additional $2 \mathrm{~d}$, lotantigen got expressed much more strongly, and the cellular morphology of lot cells became visible (Fig. $5 C$ ). A number of GFPlabeled cells horizontally lay within the lot cell array (Fig. $5 B$ ), and some of them indeed expressed lot-antigen (Fig. $5 D-F$ ). The fragmental nature of localization of lot-antigen still prohibited us from detecting all of the lot cell bodies and thus obscured what proportion of the GFP-labeled cells actually expressed lot-antigen. Nevertheless, there were apparently some GFP-labeled cells that were positioned deeper than the lot cell array, suggesting that some other types of neurons also follow the same migration course as do lot cells.

\section{Abnormal distribution of lot cells in $X t^{J}$ mutant telencephalon}

Recent studies have identified a number of molecules functioning in brain patterning (Rubenstein and Beachy, 1998). The zinc-finger type transcription factor Gli3 is one of these regulatory molecules. The $X t^{\mathrm{J}}$ mutant mouse carries a large deletion in the gli3 gene (Schimmang et al., 1992; Hui and Joyner, 1993) and shows various phenotypes, including polydactyly and brain malformations. For example, the olfactory bulbs and LOTs are totally missing in the homozygote, which is thought to be caused by the lack of innervation of the bulb rudiments by olfactory nerves (Johnson, 1967; Naruse et al., 1990; Naruse and Keino, 1993). The homozygous brains also lack the dorsomedial structures of the telencephalon such as the hippocampal primordium and choroid plexus, and sometimes show exencephaly and hydrocephaly (Franz, 1994; Grove et al., 1998; Theil et al., 1999; Tole et al., 2000).

The telencephalons of $X t^{\mathrm{J}} / X t^{\mathrm{J}}$ mutant embryos were somewhat 

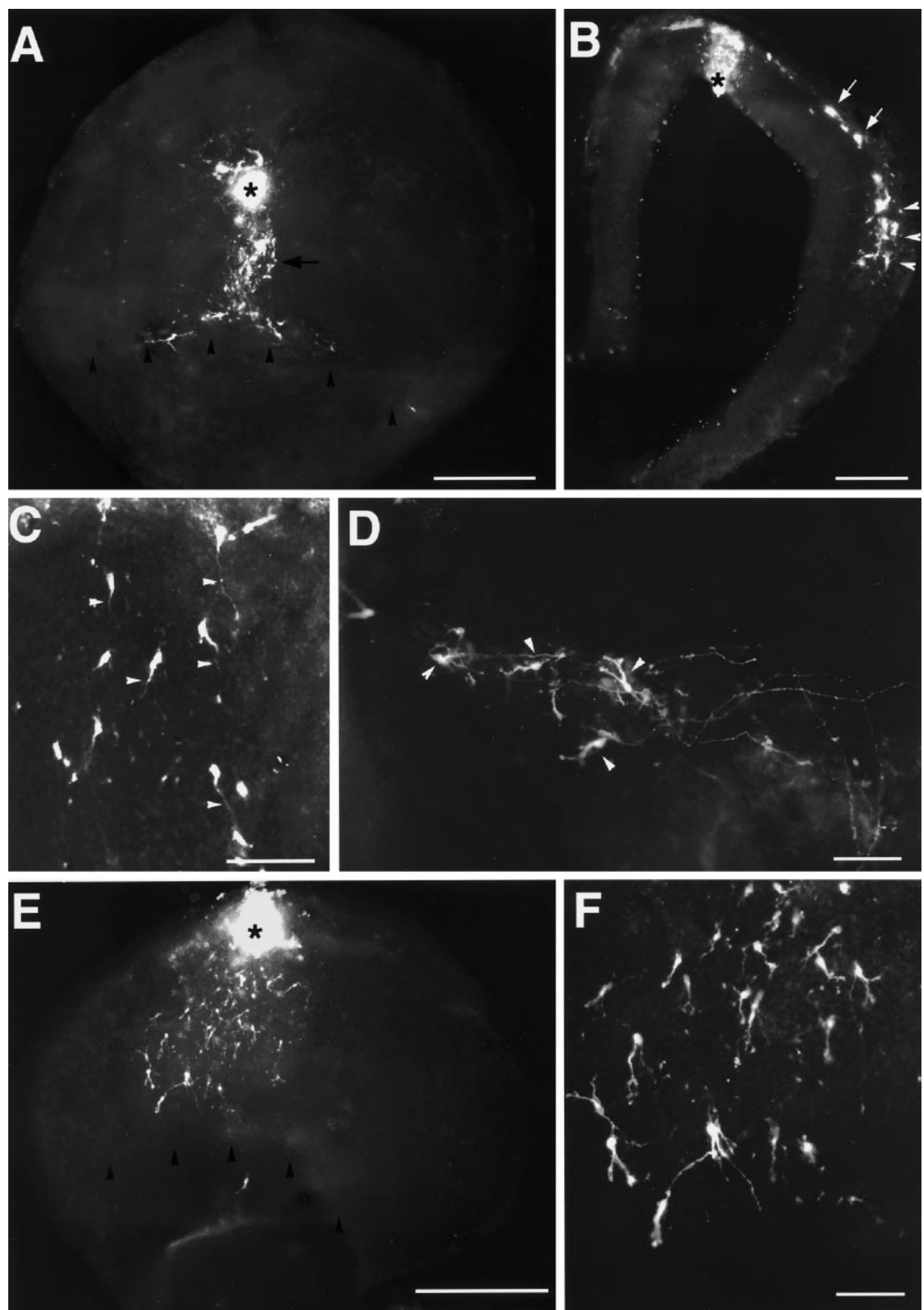

Figure 4. Migration of cells in the telencephalon. Neuroepithelial cells in the neocortex were labeled with DiI at E10.5, and distribution of the descendants was analyzed after whole embryo culture for $48 \mathrm{hr}$. A, A lateral view of the telencephalon. Dorsal is to the top, and rostral is to the left. An asterisk marks the position of DiI injection. DiI-labeled cells migrate ventrally (arrow), change their orientation, and align in the presumptive LOT position (arrowheads), drawing an inverted "T" on the surface of the telencephalon. B, A coronal section of the telencephalon. DiI was injected in the dorsal position of the neocortex (asterisk). The labeled cells migrate ventrally in the surface layer of the telencephalon (arrows) and accumulate in the presumptive LOT position (arrowheads). In this position, the labeled cells occupy both the surface layer (which usually contains lot cells) and a slightly deeper layer (which is usually devoid of lot cells). C, DiI-labeled cells between the injection point and the presumptive LOT position. The morphological features of these cells are typical of migrating neurons with their thick leading processes (arrowheads) orienting in a ventral direction (to the bottom). D, DiI-labeled cells aligning in the presumptive LOT position. The cells (arrowheads) establish long processes in the future direction of the LOT as do lot cells. E, A lateral view of the whole telencephalon given the DiI injection at E11.5. The DiI injection point is indicated by an asterisk. Migration of DiI-labeled cells is less directional than in $A$, and few cells reach the presumptive LOT position (arrowheads). $F$, A high magnification of $E$. DiI-labeled cells show complex morphology with multiple processes. Scale bars: $A, E, 500 \mu \mathrm{m} ; B, 200 \mu \mathrm{m} ; C, D, F, 100 \mu \mathrm{m}$. 

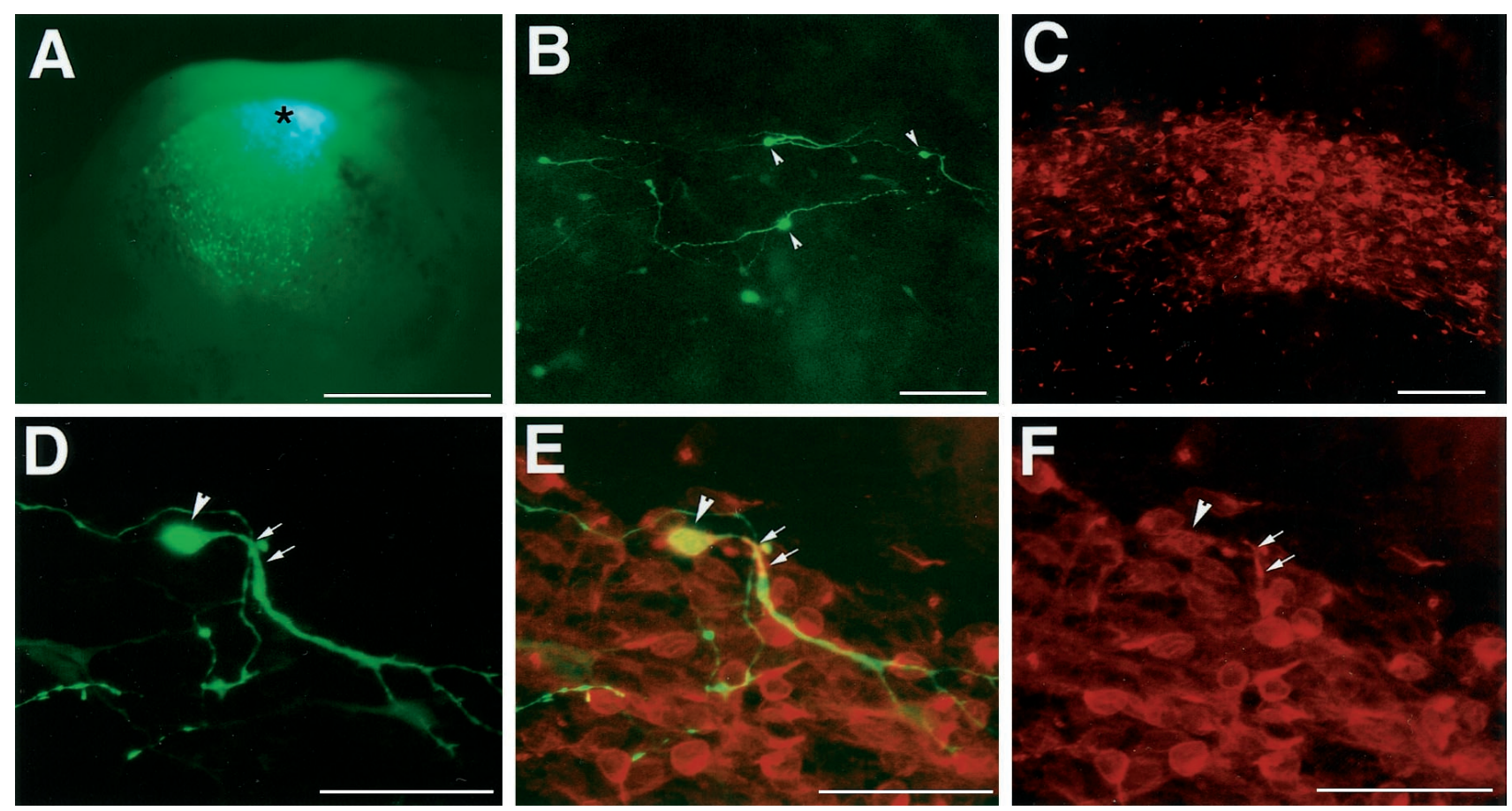

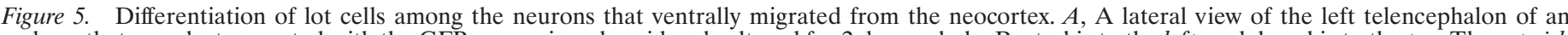

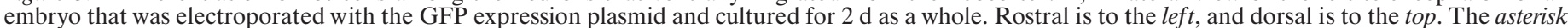

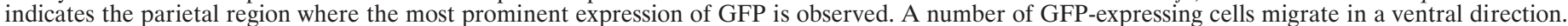

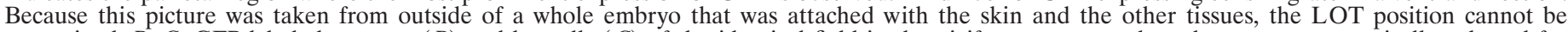

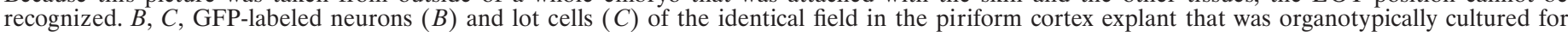

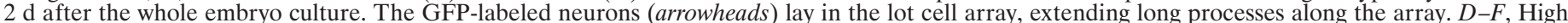

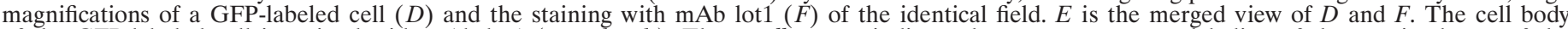

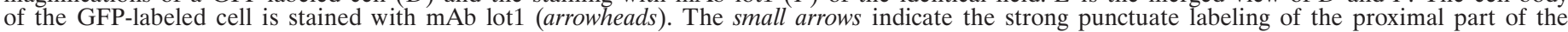

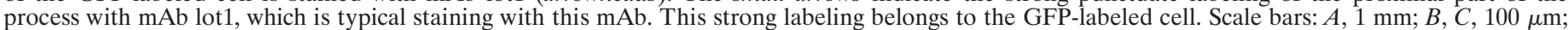
$D-F, 50 \mu \mathrm{m}$.

smaller than those of wild-type litter embryos. Lot cells were widely distributed over the entire dorsal telencephalon, forming small clusters in the $X t^{\mathrm{J}} / X t^{\mathrm{J}}$ mutant telencephalon (Fig. 6A,B). Close examination showed that a few lot cells were still localized in the normal LOT position even in the $X t^{\mathrm{J}} / X t^{\mathrm{J}}$ telencephalon, whereas the vast majority of these cells were abnormally positioned in the neocortex (Fig. 6D). Some lot cells were buried in the telencephalon wall, although this was never seen in the wild-type telencephalon in which lot cells were always positioned in the surface area (Fig. 6C). The transcription factor PAX6, a neocortexspecific marker, was expressed in the dorsal ventricular zone of $X t^{\mathrm{J}} / X t^{\mathrm{J}}$ telencephalon as wild-type telencephalon (Fig. $6 C, D$ ), suggesting that the division of the neocortex and ganglionic eminence developed even in the $X t^{\mathrm{J}} / X t^{\mathrm{J}}$ mutant telencephalon. Because the diff use distribution of lot cells in the $X t^{\mathrm{J}} / X t^{\mathrm{J}}$ telencephalon gave an impression that there were more lot cells in the mutant telencephalon, we counted the total number of lot cells per hemisphere. However, there were no significant differences in the total number of lot cells in the wild-type and $X t^{\mathrm{J}} / X t^{\mathrm{J}}$ telencephalons (data not shown).

To examine the location of lot cell generation in the $X t^{\mathrm{J}} / X t^{\mathrm{J}}$ telencephalon, dissociated cultures of E10.5 Xt $/ \mathrm{Xt}^{\mathrm{J}}$ telencephalon cells were prepared. Because intercrosses of heterozygotes yielded only a few $X t^{\mathrm{J}} / X t^{\mathrm{J}}$ embryos, we cultured telencephalon cells at a low density (see Materials and Methods). Lot cells differentiated from the neocortex but not the ganglionic eminence in $X t^{\mathrm{J}} / X t^{\mathrm{J}}$ embryos as in wild-type embryos (Table 3). Lot cells of $X t^{\mathrm{J}} / X t^{\mathrm{J}}$ embryos were morphologically indistinguishable from those of wild-type embryos in culture except that they tended to show a weaker staining with $\mathrm{mAb}$ lot1, although these differences in the staining intensity were not noted in lot cells of the telencephalon in vivo. The weaker staining of lot cells in culture appeared to be reflected in the smaller number of lot cells that were observed in
$X t^{\mathrm{J}} / X t^{\mathrm{J}}$ neocortical cultures (Table 3 ). The proportion of lot cells that incorporated BrdU in $X t^{\mathrm{J}} / X t^{\mathrm{J}}(64 \%)$ was not different from that in wild-type $(61 \%)$ cultures. Judging from the population of process-bearing cells, development of neurons seemed to be slightly impaired in $X t^{\mathrm{J}} / X t^{\mathrm{J}}$ neocortical cultures, although differences in the number of MAP2-positive cells of $X t^{\mathrm{J}} / X t^{\mathrm{J}}$ and wildtype cultures were not always statistically significant through five independent experiments (Table 3). Thus, our results could not establish whether a specific differentiation process into lot cells was impaired in cultures of $X t^{\mathrm{J}} / X t^{\mathrm{J}}$ neocortical cells or whether there was a general defect in neuronal development in $X t^{\mathrm{J}} / X t^{\mathrm{J}}$ culture that resulted in the reduced number of lot cells. Ganglionic eminence cells of $X t^{\mathrm{J}} / \mathrm{Xt}^{\mathrm{J}}$ and wild-type embryos persistently generated a similar number of MAP2-positive neurons with similar morphology in dissociated cultures (Table 3).

We finally examined the migration of cells in the $X t^{\mathrm{J}} / X t^{\mathrm{J}}$ telencephalon. DiI was injected in neocortices of $X t^{\mathrm{J}} / X t^{\mathrm{J}}$ embryos at E10.5, and the whole embryos were cultured for $48 \mathrm{hr}$. Migration of DiI-labeled cells in the $X t^{\mathrm{J}} / X t^{\mathrm{J}}$ telencephalon was not directional as in the wild-type telencephalon (Fig. $7 A, B$ ). DiI-labeled cells migrated even in a dorsal direction, and few cells reached the normal LOT position (Fig. 7B). Many DiI-labeled cells in the $X t^{\mathrm{J}} / X t^{\mathrm{J}}$ telencephalon were round-shaped and did not display a morphology typical of migrating neurons as did the cells in the wild-type telencephalon. We measured distances between the cells and the DiI injection points and observed a clear difference in distances for $X t^{\mathrm{J}} / X t^{\mathrm{J}}$ and wild-type cells. Wild-type cells migrated to a maximum of $1500 \mu \mathrm{m}$ with a small peak at $\sim 900 \mu \mathrm{m}$, whereas only a small fraction of $X t^{\mathrm{J}} / X t^{\mathrm{J}}$ cells migrated over $500 \mu \mathrm{m}$ (Fig. $7 C$ ). These results suggest that lot cells are generated in the $X t^{\mathrm{J}} / X t^{\mathrm{J}}$ telencephalon but have a defect in the migration toward the LOT position. 

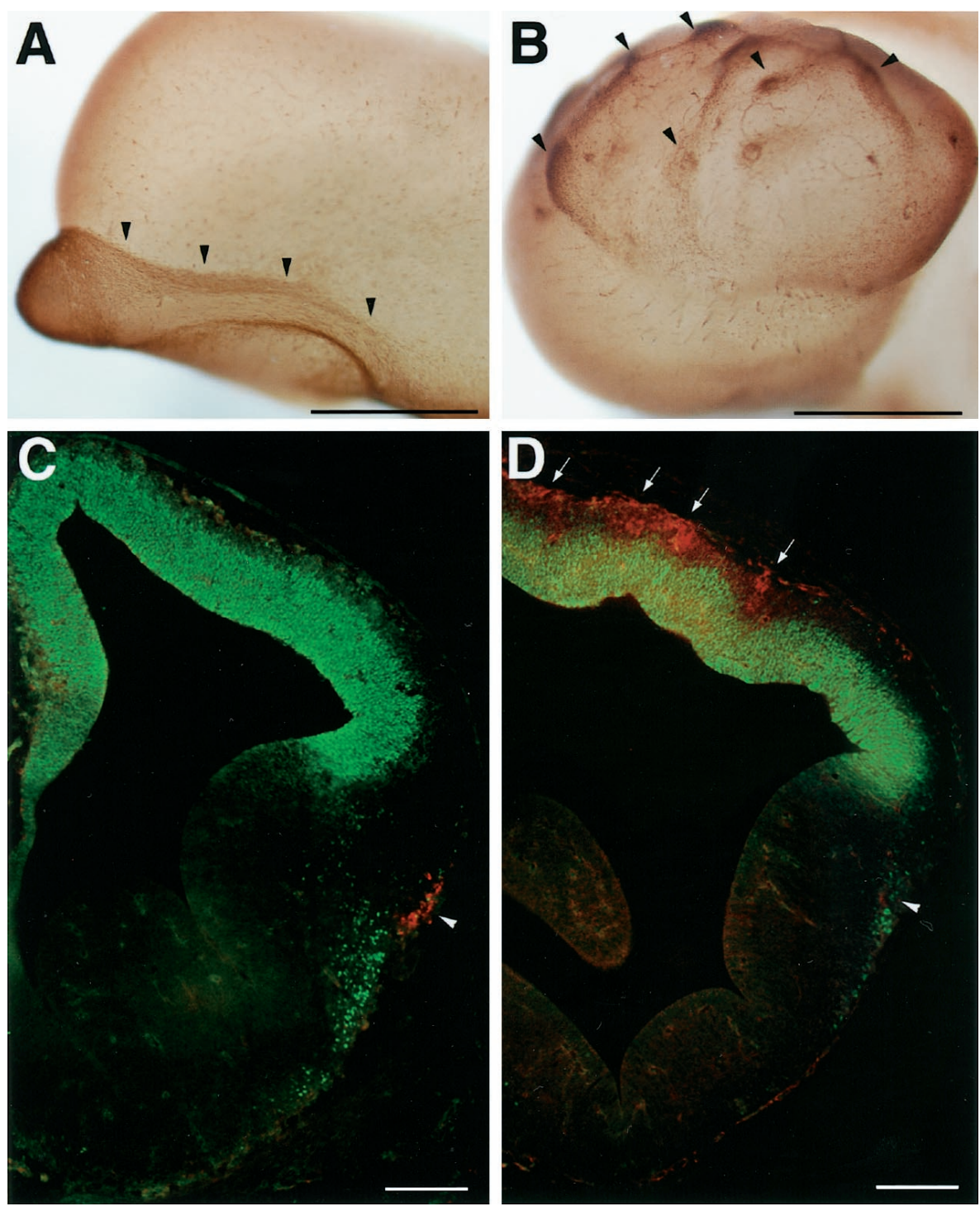

Figure 6. Distribution of lot cells in wild-type and $X t^{\mathrm{J}} / X t^{\mathrm{J}}$ telencephalons. $A, B$, Whole-mount immunostaining of E14.5 wild-type $(A)$ and $X t^{\mathrm{J}} / X t^{\mathrm{J}}(B)$ telencephalons with $\mathrm{mAb}$ lot1. Lot cells (arrowheads) align along the LOT in $A$, whereas lot cells are distributed over the entire dorsal telencephalon, forming clusters in $B$. C, D, Coronal sections of E12.5 wild-type $(C)$ and $X t^{\mathrm{J}} / X t^{\mathrm{J}}(D)$ telencephalons immunostained with mAb lot1 (red) and antiPAX6 (green) antibodies. Lot cells are localized in the LOT position in the wild-type telencephalon ( $C$, arrowhead), whereas lot cells are distributed over the entire PAX6-positive neocortex in the $X t^{\mathrm{J}} / X t^{\mathrm{J}}$ telencephalon (D, arrows). Although lot cells in the $X t^{\mathrm{J}} / X t^{\mathrm{J}}$ telencephalon seem to outnumber those in the wild-type telencephalon in this figure, actual counting of lot cells shows that both of the telencephalons have similar numbers of total lot cells. Arrowhead in $D$ indicates a small number of lot cells localized in the LOT position of the $X t^{\mathrm{J}} / X t^{\mathrm{J}}$ telencephalon. Scale bars: $A, B, 1 \mathrm{~mm}$; $C, D, 200 \mu \mathrm{m}$.

Table 3. Cell composition in dissociated cultures of E10.5 wild-type and $X t^{\mathrm{J}} / X t^{\mathrm{J}}$ telencephalon cells

\begin{tabular}{|c|c|c|c|c|c|}
\hline Genotype & Region & Total cells & BrdU-incorporated cells & MAP2-positive cells & Lot cells \\
\hline$+/+$ or $X t^{\mathrm{J}} /+$ & Neocortex & $214.7 \pm 8.3$ & $86.7 \pm 4.1$ & $43.6 \pm 4.2$ & $22.2 \pm 1.7^{a}$ \\
\hline$+/+$ or $X t^{\mathrm{J}} /+$ & Ganglionic eminence & $208.2 \pm 6.5$ & $93.8 \pm 7.1$ & $48.3 \pm 2.8$ & $0.4 \pm 0.1$ \\
\hline$X t^{\mathrm{J}} / X t^{\mathrm{J}}$ & Neocortex & $259.6 \pm 11.5$ & $83.3 \pm 7.0$ & $38.0 \pm 3.9$ & $12.1 \pm 1.2^{a, b}$ \\
\hline$X t^{\mathrm{J}} / X t^{\mathrm{J}}$ & Ganglionic eminence & $241.1 \pm 9.2$ & $104.0 \pm 9.4$ & $51.1 \pm 3.8$ & $0.4 \pm 0.1$ \\
\hline
\end{tabular}

Data are mean \pm SEM of cell numbers per $0.36 \mathrm{~mm}^{2}$. The values of lot cells were calculated from the pooled data of $83-108$ fields, and the other values were from $32-48$ fields. ${ }^{a} p<0.001$ compared with ganglionic eminence cultures of the same genotype (Student's $t$ test).

${ }^{b} p<0.001$ compared with neocortex cultures of $X t \mathrm{~J} /+$ or $+/+$ embryos (Student's $t$ test).

\section{DISCUSSION}

The present study showed that specification of the LOT is achieved through a combination of determinative events. First, generation of lot cells was restricted to neuroepithelial cells in the neocortex. At E10.5, neuroepithelial cells in all areas of the neocortex generated lot cells in culture, whereas the cells in the ganglionic eminence did not. Because a number of genes are differently expressed in the neocortex and ganglionic eminence from early development (Bulfone et al., 1993; Matsunami and Takeichi, 1995; Stoykova et al., 1996), it is not surprising that neuroepithelial cells in these two compartments are qualitatively different from each other at this stage. Neocortical neuroepithelial cells seem to be intrinsically capable of generating lot cells; a single cell proliferated and gave rise to lot cells without influence from other telencephalon cells. Although intrinsic determination of cell fate is often related to a lineage-dependent process, the whole lineage was not restricted to the fate of lot cells, because both lot cells and lot-negative neurons were generated from a common progenitor. In this regard, the developmental stage appeared to be one important determinant of lot cell fate. By E11.5, the competence to generate lot cells was almost abolished in neuroepithelial cells, and afterward, neuroepithelial cells exclusively generated lot-negative neurons, the majority of neurons in the telencephalon both in vivo and in vitro.

If lot cell precursors develop from all across the neocortex, the cells have to migrate down to the presumptive LOT position over a relatively long distance. The present study revealed that this type 

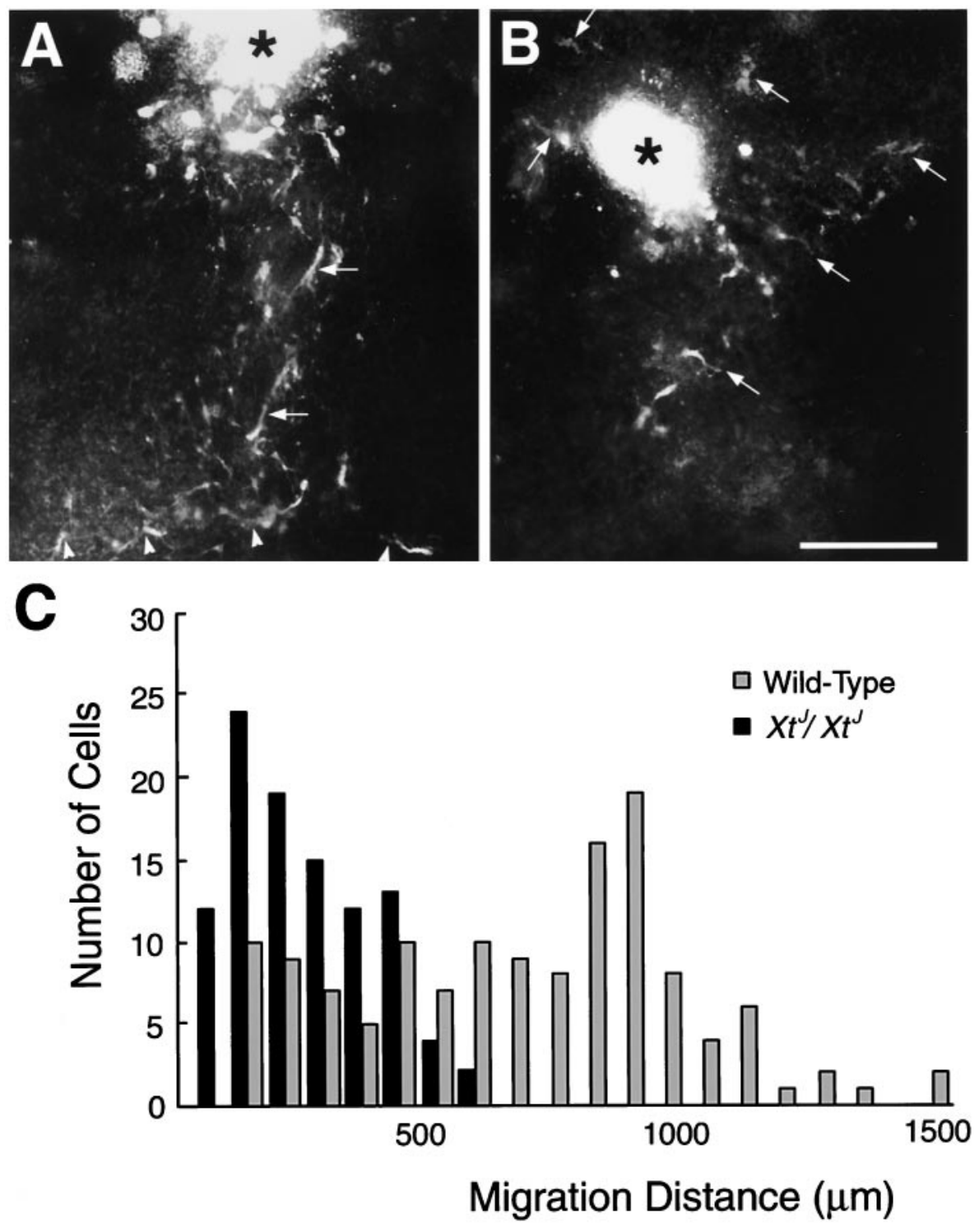

Figure 7. Cell migration in wild-type and $X t^{\mathrm{J}} / X t^{\mathrm{J}}$ telencephalons. $A, B$, Neocortices of wild-type $(A)$ and $X t^{\mathrm{J}} / X t^{\mathrm{J}}(B)$ litter embryos were labeled with DiI at E10.5, and migration of the descendants was analyzed after whole-embryo culture for 48 hr. Asterisks indicate the DiI injection sites. DiIlabeled cells migrate ventrally (arrows) and align in the presumptive LOT position (arrowheads in $A$ ), whereas the cells migrate in various directions (arrows) and do not reach the LOT position in $B$. Scale bar, $200 \mu \mathrm{m}$. $C$, A histogram showing distribution of the distances between DiI-labeled cell bodies and the DiI injection point. In the wildtype telencephalon, more than half of the cells migrate for $>500 \mu \mathrm{m}$ ( gray columns), whereas only a few cells migrate over $500 \mu \mathrm{m}$ in the $X t^{\mathrm{J}} / X t^{\mathrm{J}}$ telencephalon (black columns).

of cell migration actually existed in vivo and suggested that at least some of the migrated cells become lot cells. Firstly, the DiI-labeled cells were accumulated in the presumptive LOT position that is exclusive to lot cells. Although technical limitations prohibited us from showing directly that the migrating cells differentiated into lot cells with expressing lot-antigen, these cells were morphologically identical to lot cells. Second, the cell migration stream toward the presumptive LOT position was remarkable at E10.5 but not at E11.5. This time course is consistent with that of the generation of lot cells in vivo. Third, the results of dissociated cell cultures showed a clear ventral shift of distribution of postmitotic lot cell precursors from E10.5 to E11.5. Thus, after completing the final mitoses, lot cell precursors appeared to change their positions ventrally in vivo. Finally, a fraction of the cells that had migrated from the dorsal neocortex to the LOT position indeed expressed lot-antigen with additional explant culture. These results, together with the previous observation of the first scattered appearance of lot cells on the dorsal side of the LOT position (Sato et al., 1998), propose the following scheme: differentiation of lot cell precursors in the entire neocortex and subsequent ventral migration followed by their alignment in the future site of the LOT.

In the present study, we found that apart from lot cells, some cells also migrated with the same ventral migration stream. Although the exact fate of these neurons is unknown at present, they may differentiate into neurons in layer II of the piriform cortex, because they occupied a slightly deeper layer than layer I in which lot cells are located. In the adult piriform cortex, horizontally oriented neurons are positioned in layer I, whereas most of the layer II neurons are pyramidal or semilunar (Haberly, 1983). Thus, if the cells that ventrally migrated from the neocortex differentiate into layer II neurons, they may change the shape and orientation in succeeding development. In any case, the ventral migration seems to be a common pathway for neurons to follow at this stage and definitely deserves further investigation. Neurons in layer III of the piriform cortex are shown to derive from the ganglionic eminence with another migration stream (De Carlos et al., 1996). Thus, different layers of the piriform cortex appeared to be populated with neurons of different origins and different migration routes.

In the $X t^{\mathrm{J}} / X t^{\mathrm{J}}$ mutant telencephalon, lot cells were abnormally distributed over the entire neocortex. A defect in cell migration appeared to be the main cause of this phenotype. The Gli protein family is a vertebrate homolog of Drosophila cubitus interruptus $(\mathrm{ci})$, which is involved in hedgehog signaling (Hui et al., 1994). Among three members of Gli family, Gli3 is suggested to be a negative regulator of sonic hedgehog signaling (Masuya et al., 1995; Sasaki et al., 1997). Although we could not detect expression of Gli3 in lot cells localized in the LOT position (data not shown), Gli3 is strongly expressed in the neocortical ventricular zone (Hui et al., 1994; Grove et al., 1998), indicating that at least lot cell precursors in the ventricular zone express Gli3. Therefore, we 
cannot determine whether Gli3 acts cell-autonomously or non-cellautonomously in the migration of lot cell precursors. The possible role for Gli3 as an intracellular signaling molecule may suggest Gli3 autonomy in lot cell precursors. The observation that differentiation into lot cells was impaired in a low-density culture of $X t^{\mathrm{J}} / X t^{\mathrm{J}}$ neocortical cells might favor this hypothesis. Alternatively, mutation of Gli3 may disturb dorsoventral patterning of the brain, which may lead to disruption of positional information for the migration of lot cell precursors. Although the expression pattern of Pax6 suggests that the division of the neocortex and ganglionic eminence develops in the $X t^{\mathrm{J}} / X t^{\mathrm{J}}$ telencephalon, this mutant telencephalon lacks the more dorsomedial structures such as the hippocampal primordium and choroid plexus (Grove et al., 1998; Theil et al., 1999; Tole et al., 2000). One interesting possibility may be that these dorsomedial structures repel lot cell precursors and direct them into the ventral direction. In either case, further analyses of lot cells in the $X t^{\mathrm{J}} / X t^{\mathrm{J}}$ telencephalon will help us understand the migration process of lot cell precursors.

The present study did not investigate the mechanisms of how neuronal migration terminates in the LOT position. It is highly likely that certain signals trigger the settlement of migrating cells. One interesting candidate for the source of this signal may be the boundary between the neocortex and the ganglionic eminence. In the ventricular zone, this boundary acts as a barrier to restrict cell movement (Fishell et al., 1993). Moreover, some neurons align along the boundary in culture (Neyt et al., 1997). Although the boundary is located in the ventricular zone, ventricular cells project long radial fibers outward to the pial surface, forming a prominent fascicle (De Carlos et al., 1996; Misson et al., 1988). In fact, our preliminary study suggests that ventricular cells in the neocortexganglionic eminence boundary selectively project radial fibers to the LOT position (N. Osumi, N. Tomioka, and T. Hirata, unpublished observations). The next question will be whether these radial fibers exert a barrier-like action on migration of lot cells.

Studies on the regional specification of the telencephalon have generated a number of hypotheses (McConnell, 1992; O'Leary et al., 1992; Rakic, 1995; Fishell, 1997; Levitt et al., 1997). The present analysis in the telencephalon provides a new scheme of regional specification: early restriction of competence for a regional phenotype in a large area and subsequent migration of the specified cells into a smaller restricted region. Therefore, in this case, tangential migration does not mean dispersion of the regional phenotype, but conversely leads to the establishment of the regional specification. Although we do not know why the specification of LOT needs such a complicated scenario, a combination of determinative events appears to be a common feature in determination of neuronal fate. Neurons have various aspects of identity, e.g., morphological characteristics, neurotransmitter types, connection patterns, etc., and these different aspects are determined by distinct mechanisms (McConnell and Kaznowski, 1991; Mione et al., 1994; Tan et al., 1998). In this sense, a combination of determinative events could define a more restricted population of neurons, which have truly the same identity. How to integrate these accumulated experimental data and compile a picture of the way that enormous diversities of neurons are achieved in the telencephalon appear to be an important issue for future study.

\section{REFERENCES}

Akamatsu W, Okano HJ, Osumi N, Inoue T, Nakamura S, Sakakibara S-I, Miura M, Matsuo N, Darnell RB, Okano H (1999) Mammalian ELAVlike neuronal RNA-binding proteins $\mathrm{HuB}$ and $\mathrm{HuC}$ promote neuronal development in both the central and the peripheral nervous systems. Proc Natl Acad Sci USA 96:9885-9890.

Anderson SA, Eisenstat DD, Shi L, Rubenstein JLR (1997) Interneuron migration from basal forebrain to neocortex: dependence on Dlx genes. Science 278:474-476.

Arimatsu Y, Miyamoto M, Nihonmatsu I, Hirata K, Uratani Y, Hatanaka Y, Takiguchi-Hayashi K (1992) Early regional specification for a molecular neuronal phenotype in the rat neocortex. Proc Natl Acad Sci USA 89:8879-8883.

Barbe MF, Levitt P (1991) The early commitment of fetal neurons to the limbic cortex. J Neurosci 11:519-533.
Brunjes PC, Frazier LL (1986) Maturation and plasticity in the olfactory system of vertebrates. Brain Res Rev 11:1-45.

Bulfone A, Puelles L, Porteus MH, Frohman MA, Martin GR, Rubenstein JLR (1993) Spatially restricted expression of Dlx-1, Dlx-2 (Tes-1), $G b x-2$, and Wnt-3 in the embryonic day 12.5 mouse forebrain defines potential transverse and longitudinal segmental boundaries. J Neurosci $13: 3155-3172$

Cohen-Tannoudji M, Babinet C, Wassef M (1994) Early determination of a mouse somatosensory cortex marker. Nature 368:460-463.

Davis JA, Reed RR (1996) Role of Olf-1 and Pax-6 transcription factors in neurodevelopment. J Neurosci 16:5082-5094.

De Carlos JA, Lópes-Mascaraque L, Valverde F (1996) Dynamics of cell migration from the lateral ganglionic eminence in the rat. $\mathrm{J}$ Neurosci 16:6146-6156.

Dehay C, Giroud P, Berland M, Smart I, Kennedy H (1993) Modulation of the cell cycle contributes to the parcellation of the primate visual cortex. Nature 366:464-466.

Fishell G (1997) Regionalization in the mammalian telencephalon. Curr Opin Neurobiol 7:62-69.

Fishell G, Mason CA, Hatten ME (1993) Dispersion of neural progenitors within the germinal zones of the forebrain. Nature 362:636-638.

Franz T (1994) Extra-toes (Xt) homozygous mutant mice demonstrate a role for the gli-3 gene in the development of the forebrain. Acta Anat 150:38-44.

Götz M, Wizenmann A, Reinhardt S, Lumsden A, Price J (1996) Selective adhesion of cells from different telencephalic regions. Neuron 16:551-564.

Grove EA, Tole S, Limon J, Yip L-W, Ragsdale CW (1998) The hem of the embryonic cerebral cortex is defined by the expression of multiple wnt genes and is compromised in gli3-deficient mice. Development 125:2315-2325.

Haberly LB (1983) Structure of the piriform cortex of the opossum. I. Description of neuron types with Golgi methods. J Comp Neurol 213:163-187.

Hinds JW (1972) Early neuron differentiation in the mouse olfactory bulb. I. Light microscopy. J Comp Neurol 146:233-252.

Hirata T, Fujisawa H (1999) Environmental control of collateral branching and target invasion of mitral cell axons during development. J Neurobiol 38:93-104.

Hui C-C, Joyner AL (1993) A mouse model of Greig cephalopolysyndactyly syndrome: the extra-toes ${ }^{\mathrm{J}}$ mutation contains an intragenic deletion of the gli3 gene. Nat Genet 3:241-245.

Hui C-C, Slusarski D, Platt KA, Holmgren R, Joyner AL (1994) Expression of three mouse homologues of the Drosophila segment polarity gene cubitus interruptus, Gli, Gli-2, and Gli-3, in ectoderm- and mesodermderived tissues suggests multiple roles during postimplantation development. Dev Biol 162:402-413.

Inouye S, Ogawa H, Yasuda K, Umesono K, Tsuji FI (1997) A bacterial cloning vector using a mutated Aequorea green fluorescent protein as an indicator. Gene 189:159-162.

Johnson DR (1967) Extra-toes: a new mutant gene causing multiple abnormalities in the mouse. J Embryol Exp Morph 17:543-581.

Kornack DR, Rakic P (1995) Radial and horizontal deployment of clonally related cells in the primate neocortex: relationship to distinct mitotic lineages. Neuron 15:311-321.

Levitt P, Barbe MF, Eagleson KL (1997) Patterning and specification of the cerebral cortex. Annu Rev Neurosci 20:1-24.

Macdonald R, Xu Q, Barth KA, Mikkola I, Holder N, Fjose A, Krauss S, Wilson SW (1994) Regulatory gene expression boundaries demarcate sites of neuronal differentiation in the embryonic zebrafish forebrain. Neuron 13:1039-1053.

Mastick GS, Easter Jr SS (1996) Initial organization of neurons and tracts in the embryonic mouse fore-and midbrain. Dev Biol 173:79-94.

Mastick GS, Davis NM, Andrews GL, Easter Jr SS (1997) Pax-6 functions in boundary formation and axon guidance in the embryonic mouse forebrain. Development 124:1985-1997.

Masuya H, Sagai T, Wakana S, Moriwaki K, Shiroishi T (1995) A duplicated zone of polarizing activity in polydactylous mouse mutants. Genes Dev 9:1645-1653.

Matsunami H, Takeichi M (1995) Fetal brain subdivisions defined by Rand E-cadherin expressions: evidence for the role of cadherin activity in region-specific, cell-cell adhesion. Dev Biol 172:466-478.

Matsuo T, Osumi-Yamashita N, Noji S, Ohuchi H, Koyama E, Myokai F, Matsuo N, Taniguchi S, Doi H, Iseki S, Ninomiya Y, Fujiwara M, Watanabe T, Eto K (1993) A mutation in the Pax-6 gene in rat small eye is associated with impaired migration of midbrain crest cells. Nat Genet 3:299-304.

McConnell SK (1992) The control of neuronal identity in the developing cerebral cortex. Curr Opin Neurobiol 2:23-27.

McConnell SK, Kaznowski CE (1991) Cell cycle dependence of laminar determination in developing neocortex. Science 254:282-285.

Mione MC, Danevic C, Boardman P, Harris B, Parnavelas JG (1994) Lineage analysis reveals neurotransmitter (GABA or glutamate) but not calcium-binding protein homogeneity in clonally related cortical neurons. J Neurosci 14:107-123.

Misson J-P, Edwards MA, Yamamoto M, Caviness Jr VS (1988) Identification of radial glial cells within the developing murine central nervous 
system: studies based upon a new immunohistochemical marker. Dev Brain Res 44:95-108.

Miyata T, Ogawa M (1994) Developmental potentials of early telencephalic neuroepithelial cells: a study with microexplant culture. Dev Growth Differ 36:319-331.

Naruse I, Keino H (1993) Induction of agenesis of the corpus callosum by the destruction of anlage of the olfactory bulb using fetal laser surgery exo utero in mice. Dev Brain Res 71:69-74.

Naruse I, Kato K, Asano T, Suzuki F, Kameyama Y (1990) Developmental brain abnormalities accompanied with the retarded production of $\mathrm{S}-100 \beta$ protein in genetic polydactyly mice. Dev Brain Res 51:253-258.

Neyt C, Welch M, Langston A, Kohtz J, Fishell G (1997) A short-range signal restricts cell movement between telencephalic proliferative zones. J Neurosci 17:9194-9203.

Okabe M, Ikawa M, Kominami K, Nakanisi T, Nisimune Y (1997) "Green mice" as a source of ubiquitous green cells. FEBS Lett 407:313-319.

O'Leary DDM, Schlaggar BL, Stanfield BB (1992) The specification of sensory cortex: lessons from cortical transplantation. Exp Neurol 115:121-126.

O'Rourke NA, Dailey ME, Smith SJ, McConnell SK (1992) Diverse migratory pathways in the developing cerebral cortex. Science 258:299-302.

Osumi-Yamashita N, Ninomiya YN, Doi H, Eto K (1994) The contribution of both forebrain and midbrain crest cells to the mesenchyme in the frontonasal mass of mouse embryos. Dev Biol 164:409-419.

Rakic P (1995) Radial versus tangential migration of neuronal clones in the developing cerebral cortex. Proc Natl Acad Sci USA 92:11323-11327.

Rakic P (1988) Specification of cerebral cortical areas. Science 241:170-176.

Rubenstein JLR, Beachy PA (1998) Patterning of the embryonic forebrain. Curr Opin Neurobiol 8:18-26.

Sakakibara S-I, Imai T, Hamaguchi K, Okabe M, Aruga J, Nakajima K, Yasutomi D, Nagata T, Kurihara Y, Uesugi S, Miyata T, Ogawa M, Mikoshiba K, Okano H (1996) Mouse-Musashi-1, a neural RNAbinding protein highly enriched in the mammalian CNS stem cell. Dev Biol 176:230-242.

Sasaki H, Hui C-C, Nakafuku M, Kondoh H (1997) A binding site for Gli proteins is essential for HNF-3 $\beta$ floor plate enhancer activity in transgenics and can respond to Shh in vitro. Development 124:1313-1322.

Sato Y, Hirata T, Ogawa M, Fujisawa H (1998) Requirement for early- generated neurons recognized by monoclonal antibody lot1 in the formation of lateral olfactory tract. J Neurosci 18:7800-7810.

Schimmang T, Lemaistre M, Vortkamp A, Rüther U (1992) Expression of the zinc finger gene gli3 is affected in the morphogenetic mouse mutant extra-toes (Xt). Development 116:799-804.

Schlaggar BL, O'Leary DDM (1991) Potential of visual cortex to develop an array of functional units unique to somatosensory cortex. Science 252:1556-1560.

Schwob JE, Price JL (1984) The development of lamination of afferent fibers of the olfactory cortex in rats, with additional observations in the adult. J Comp Neurol 223:203-222.

Stanfield BB, O'Leary DDM (1985) Fetal occipital cortical neurones transplanted to the rostral cortex can extend and maintain a pyramidal tract axon. Nature 313:135-137.

Stoykova A, Fritsch R, Walther C, Gruss P (1996) Forebrain patterning defects in small eye mutant mice. Development 122:3453-3465.

Sugisaki N, Hirata T, Naruse I, Kawakami A, Kitsukawa T, Fujisawa H (1996) Positional cues that are strictly localized in the telencephalon induce preferential growth of mitral cell axons. J Neurobiol 29:127-137.

Tamamaki N, Fujimori KE, Takauji R (1997) Origin and route of tangentially migrating neurons in the developing neocortical intermediate zone. J Neurosci 17:8313-8323.

Tan S-S, Breen S (1993) Radial mosaicism and tangential cell dispersion both contribute to mouse neocortical development. Nature 362:638-640.

Tan S-S, Kalloniatis M, Sturm K, Tam PPL, Reese BE, Faulkner-Jones B (1998) Separate progenitors for radial and tangential cell dispersion during development of the cerebral neocortex. Neuron 21:295-304.

Tessier-Lavigne M, Goodman CS (1996) The molecular biology of axon guidance. Science 274:1123-1131.

Theil T, Alvarez-Bolado G, Walter A, Rüther U (1999) Gli3 is required for Emx gene expression during dorsal telencephalon development. Development 126:3561-3571.

Tole S, Ragsdale CW, Grove EA (2000) Dorsoventral patterning of the telencephalon is disrupted in the mouse mutant extra-toes ${ }^{\mathrm{J}}$. Dev Biol 217:254-265.

Walsh C, Cepko CL (1992) Widespread dispersion of neuronal clones across functional regions of the cerebral cortex. Science 255:434-440. 